\title{
Response of the sea whip Halipteris willemoesi to simulated trawl disturbance and its vulnerability to subsequent predation
}

\author{
Patrick W. Malecha*, Robert P. Stone \\ Auke Bay Laboratories, Alaska Fisheries Science Center, National Marine Fisheries Service, National Oceanic and \\ Atmospheric Administration, 17109 Point Lena Loop Road, Juneau, Alaska 99801, USA
}

\begin{abstract}
The sea whip Halipteris willemoesi occurs in habitats coincident with bottom trawl fisheries in the Gulf of Alaska and Bering Sea and can be damaged by passing trawls. Little is known about the long-term fate of sea whips damaged by trawl gear. Sea whip responses to simulated trawl disturbance were observed in situ over a period of about $1 \mathrm{yr}$ in order to assess delayed mortality from sublethal injuries. Colonies of $H$. willemoesi were randomly assigned to 3 treatment groups and 1 control group. Treatments were designed to mimic trawl damage including dislodgement, fracture of the axial rod, and soft tissue abrasion. Fifty percent of dislodged colonies demonstrated the ability to rebury their peduncles and recover to an erect position. Most of these colonies eventually became dislodged again without further disturbance and only one was erect at the final observation. None of the fractured colonies were able to repair their axial rods and only one was erect at the experiment's conclusion. Light tissue abrasion caused only minor tissue losses that lessened over time, and all abraded and control colonies remained erect throughout the experiment. Tissue losses among the dislodged and fractured sea whips increased throughout the experimental period and were mainly due to predation by the nudibranch Tritonia diomedea, which appeared to react with a strong scavenging response to sea whips lying on the seafloor. The presence of predators in areas where sea whips are disturbed may exacerbate trawl effects since damaged or dislodged colonies are more vulnerable to predation.
\end{abstract}

KEY WORDS: Trawling · Sea whip · Halipteris willemoesi - Seafloor habitat · Nudibranch · Tritonia diomedea

Resale or republication not permitted without written consent of the publisher

\section{INTRODUCTION}

The interaction between bottom trawls and seafloor habitats has been the focus of much research in recent years (for reviews see Watling \& Norse 1998, Auster \& Langton 1999, Collie et al. 2000, National Research Council 2002). The relative effect of bottom trawls on benthic habitat depends on many factors including gear configuration, the geological characteristics of the seafloor, depth, and the presence of habitat-forming species (Kaiser et al. 2002). Stable deep-water habitats experience low levels of natural disturbance, are more susceptible to trawl effects, and recover more slowly than dynamic shallow-water habitats (Collie et al.
2000). The response of sessile benthic epifauna to trawl disturbance varies among taxa. Species belonging to the class Anthozoa (corals, anemones, sea pens, and sea whips) are particularly sensitive to trawl disturbances and have strong negative responses (Collie et al. 2000). Sea whips (order Pennatulacea) are colonial octocorals (subclass Octocorallia) that occur in deepwater habitats. In the North Pacific Ocean and Bering Sea, they are broadly distributed on continental shelf and slope habitats coincident with bottom trawl fisheries (Malecha et al. 2005) at depths between 3 and at least 2947 m (Stone \& Shotwell 2007). The distribution of trawl effort on Alaska's continental shelf is patchy. During the period 1997 to 2001, trawl intensity for the 
entire shelf averaged $2.4 \%$ swept annually, but in the Bering Sea and Gulf of Alaska many areas were trawled more than 5 times per year and one area was trawled 17 times per year (Rose \& Jorgensen 2005). Similar intensities have been reported for heavily trawled areas on both sides of the Atlantic Ocean (Floderus \& Pihl 1990, Auster et al. 1996).

Sea whips have a relatively simple morphology consisting of a bulbous basal peduncle (which serves as an anchor in soft sediments) and a vertical rachis or shaft extending distally from the peduncle. An axial rod, composed of magnesium calcite, supports the entire colony, and the rachis is populated with rows of polyps. Ten species of pennatulaceans are known to occur in Alaska (Stone \& Shotwell 2007) and size varies considerably among species. Halipteris willemoesi Kölliker, 1870 (von Kölliker 1870) can reach heights greater than $300 \mathrm{~cm}$ (Stone \& Shotwell 2007), while Protoptilum sp. may reach just $35 \mathrm{~cm}$. Sea whips can form dense groves that provide vertical structure to low relief habitats. In Alaska, Stone et al. (2005) found densities at least as high as 16 and $6 \mathrm{~m}^{-2}$ for adult specimens of Protoptilum sp. and $H$. willemoesi, respectively. In British Columbia, Troffe et al. (2005) found densities of juvenile ( 3 to $7 \mathrm{~mm}$ ) $H$. willemoesi as high as $145 \mathrm{~m}^{-2}$. The structure provided by sea whips may be important for enhancing prey availability and providing cover from predators. Pacific ocean perch Sebastes alutus have been observed associated with $H$. willemoesi, taking cover in sea whip groves during evening hours and feeding on euphausiids above the groves during the day (Brodeur 2001). Sea whips may also be important for enhancing production at lower trophic levels. Prey taxa commonly utilized by Alaska groundfish were more abundant inside dense sea whip groves than in similar habitat with few or no sea whips (Stone et al. 2005).

Sea whip groves disturbed by fishing activities may require long periods of time to recover because colonies are believed to be slow-growing and longlived. Based on axial rod growth rings assumed to be annuli, the average age of Halipteris willemoesi ranging in length from 152 to $167 \mathrm{~cm}$ was estimated at $44.3 \pm 2.0 \mathrm{yr}(\mathrm{SE})$ and linear growth was $3.6 \pm 0.1 \mathrm{~cm}$ $\mathrm{yr}^{-1}$ (Wilson et al. 2002). Assuming this ageing technique is accurate, the maximum age of $H$. willemoesi could be substantially greater, considering that Wilson et al. (2002) suggest that growth appeared asymptotic and that colonies as large as $300 \mathrm{~cm}$ have been observed. Little is known about sea whip reproductive ecology and recruitment dynamics, both of which may be sporadic. Slow growth and inconsistent recruitment may result in low colonization rates in undisturbed areas. In disturbed areas, sea whip colonization rates may be considerably slower because damaged sea whips may reallocate energy reserves typically used for reproduction to repair injured somatic tissue. This process has been observed among other injured octocorals (Wahle 1983) and among other corals and sponges (for review see Henry \& Hart 2005).

The vertical nature of pennatulaceans makes them particularly vulnerable to damage from mobile trawl gear. While some species, such as Ptilosarcus gurneyi, are capable of retracting completely within the sediment (Birkeland 1974), Halipteris willemoesi colonies are not, and are often entangled in various components of trawl gear which can abrade or strip tissue from their axial rods. The muscular peduncle, which hydrostatically anchors sea whip colonies in sediment, can be dislodged when brought into contact with or entangled in trawl gear, and the relatively rigid axial rod of sea whips can be fractured when bent at an extreme angle, such as when it encounters trawl gear. In the Gulf of Alaska, the immediate effects of trawling on sea whips have been studied and they are substantial. A single trawl pass with rockhopper tire gear fractured or dislodged $55 \%$ of sea whips (Freese et al. 1999) and a single trawl pass with mud gear, designed to catch flatfish, fractured, dislodged, or caused tissue injuries to $24 \%$ of $H$. willemoesi (authors' pers. obs.). While these observations clearly provide evidence that trawling disturbs sea whip habitat, the long-term effects of trawling-induced damage to sea whips are unknown, as is the fate of sea whips that are dislodged, have fractured axial rods or soft tissue abrasions. In the present study, we simulated trawl-induced disturbance and/or damage to the sea whip $H$. willemoesi and observed colonies in situ over a period of approximately $1 \mathrm{yr}$ to determine their ability to recover.

\section{MATERIALS AND METHODS}

A grove (approximately $2500 \mathrm{~m}^{2}$ ) of Halipteris willemoesi southeast of Coghlan Island in Auke Bay, Alaska, served as our study site (Fig. 1). Within the grove we identified a $500 \mathrm{~m}^{2}$ experimental area that contained approximately 250 colonies at depths ranging from 21 to $30 \mathrm{~m}$. The experimental area is located on a $30^{\circ}$ slope and receives relatively little anthropogenic seafloor disturbance (i.e. commercial fishing does not occur in the immediate area). Scuba divers swam indiscriminately through the experimental area and placed numbered stakes near the base of 48 colonies (Fig. 2). Colonies were selected to allow adequate spacing (approx. $3 \mathrm{~m}$ ) between experimental subjects. Spacing ensured negligible physical interaction between colonies and divers. Divers selected colonies that ranged in length from approximately 130 to $160 \mathrm{~cm}$. When stakes were in place, 12 colonies were 


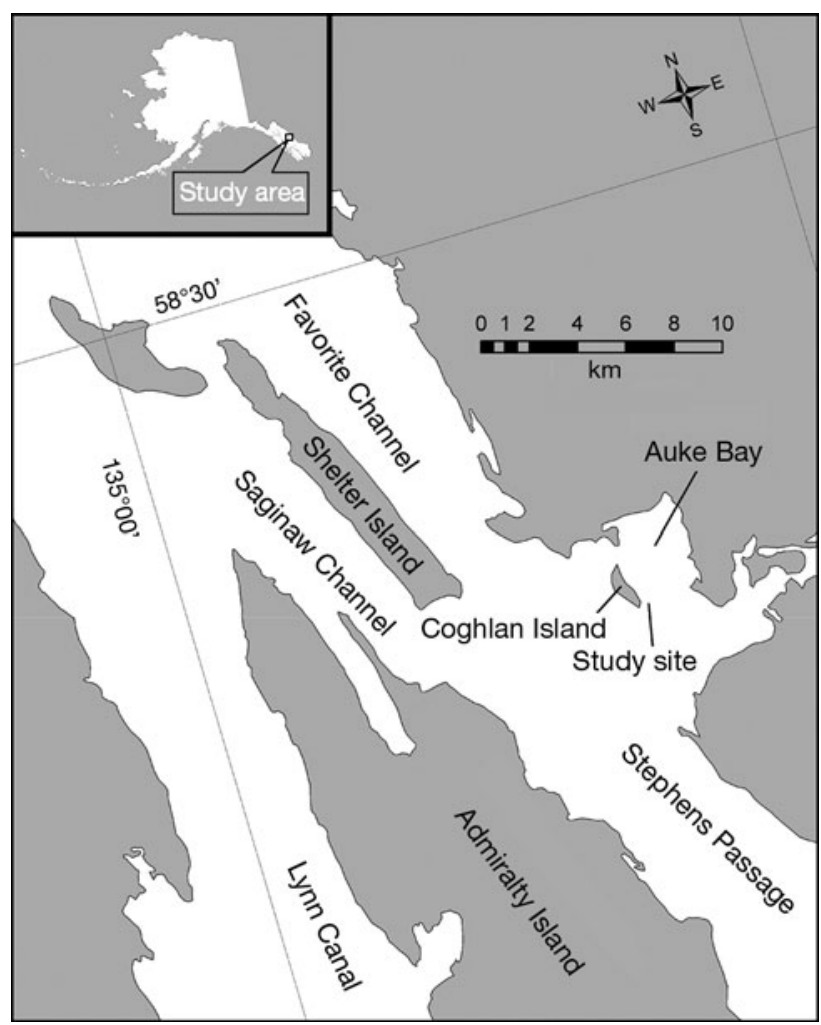

Fig. 1. Study site near Coghlan Island in Auke Bay, southeast Alaska assigned by a random draw to each of 4 treatment groups (1 control and 3 experimental). Treatments were designed to simulate trawl-induced damage observed in situ (Freese et al. 1999) and included dislodgement, fracture of the axial rod, and light tissue abrasion. The 4 treatment groups are hereafter referred to as dislodged, fractured, abraded, and control groups. Dislodgement was performed by carefully unearthing colonies and tethering them to their identifying stakes. Tethering of dislodged sea whips was necessary to prevent current and predators from removing them from the experimental area. Tethers (polyester fishing line) were attached with a pair of cable ties loosely cinched approximately $10 \mathrm{~cm}$ above the sea whip peduncle. Axial rods were fractured by holding one hand at the base of an upright sea whip and applying torsional pressure downward with the other hand until the axial rod snapped. The peduncle of fractured sea whips was not removed from the seafloor. In some instances, the fractured axial rod punctured the overlying tissue, as is the case in an open compound bone fracture. Light tissue abrasion was performed by sliding colonies between 2 rubber discs. The discs were similar to 'cookies', circular rubber tire punch-outs that are installed inline on the footrope of many bottom trawls. Previous to this experiment, we had observed colonies snagged between discs on trawl footropes.

Trawl damage simulations were completed on 6 March 2003 and videographic documentation began

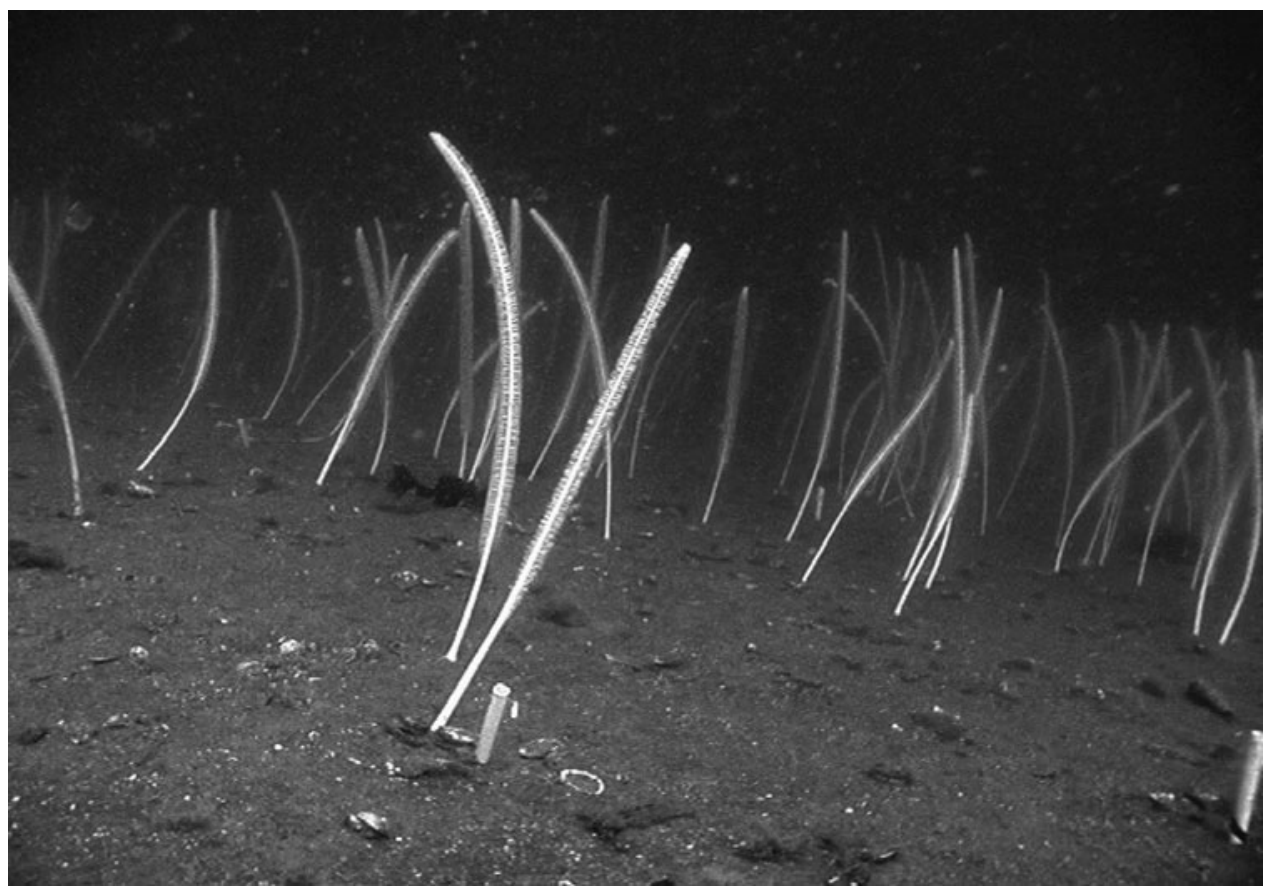

Fig. 2. Halipteris willemoesi. In situ H. willemoesi near Coghlan Island in Auke Bay, southeast Alaska. An identifying stake is located just to the right of the sea whip in the foreground 
the following day. During the first 3 mo scuba divers conducted a video survey of tagged sea whips approximately weekly. After that, observations occurred approximately monthly for 7 mo. A final observation occurred on 12 March 2004, a total of 372 d after the trawl damage simulations had been performed. Due to time limitations at depth, about half of the tagged sea whips could be observed during each video transect. The elongated experimental area is oriented roughly north to south, along the depth contour. Therefore, video transects began at alternating ends of the experimental area to increase the chances that all sea whips would be observed during consecutive surveys. Complete censuses (all sea whips observed) were obtained 18 and 104 d post-treatment and on the final observation date. Individual colony responses to treatments were qualitatively determined from videotape and included physical orientation, presence of soft tissue loss as evidenced by exposed axial rod, and percentage of soft tissue loss. The orientation of sea whips was ascribed to 1 of 2 categories: if the distal end of a sea whip was in contact with the seafloor, the sea whip was designated as prone; if the distal end of a sea whip was not in contact with the seafloor, the sea whip was designated as erect. Physical orientation of sea whips and the presence of tissue loss was compared between groups using G-tests for independence and heterogeneity; to account for non-normality of residuals, the average amount of tissue loss on sea whips was compared between groups with Kruskal-Wallis tests and nonparametric multiple comparisons by simultaneous test procedures (Sokal \& Rohlf 1995). Statistical tests were only performed on the complete data sets collected 18, 104, and $372 \mathrm{~d}$ post-treatment.

Both erect and prone sea whips exhibited soft tissue loss (i.e. exposed axial rods) that was likely sometimes due to the trawl simulations, but more often was the result of opportunistic predation by the rosy tritonia nudibranch Tritonia diomedea on sea whips lying on the seafloor. Mostly consumed (less than 10\% of their tissue remaining) colonies lying on the seafloor were left in the experimental area for at least a week but were then designated as unable to recover and removed from the area. For the statistical analyses of all subsequent observations, removed colonies were assumed to be prone with $10 \%$ of tissue remaining. We made no attempts to remove the nudibranchs, or any other predators, from the experimental area. Censuses of the nudibranchs were performed opportunistically in conjunction with video transects by swimming through the experimental area and recording the number of individuals observed. Fluctuating visibility reduced the reliability of these counts; therefore, census data cannot be considered robust but are presented as informational.
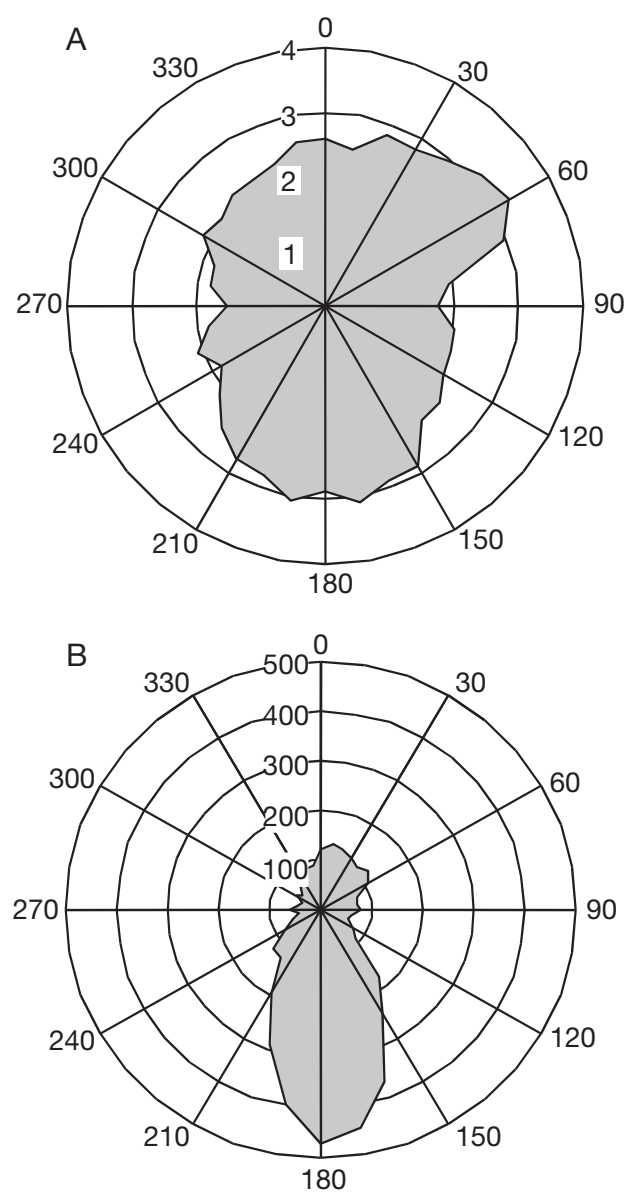

Fig. 3. (A) Mean velocity of benthic current and (B) frequency of current headings at the Coghlan Island Halipteris willemoesi study site between 6 February and 11 March 2004. Total number of measurements equals 4915. Radiating lines are headings in degrees relative to true north. Concentric circles indicate (A) velocity in $\mathrm{cm} \mathrm{s}^{-1}$ and (B) number of observations

Between 6 February and 11 March 2004, a SonTek Argonaut ${ }^{\circledR}$-MD1 Doppler current meter equipped with an internal compass was moored off bottom at the study site. The meter recorded current velocity $\left( \pm 0.5 \mathrm{~cm} \mathrm{~s}^{-1}\right)$ and heading $\left( \pm 2^{\circ}\right)$ of a $1 \mathrm{~m}$ cell of water $0.5 \mathrm{~m}$ above the seafloor. The current meter measured velocity and direction once per second. However, to conserve data storage space, the current meter was programmed to record velocity and direction once every $10 \mathrm{~min}$ based on an average of observations from a 3 min interval. Benthic current velocity in the study area varied little with current direction during the sampling period, and averaged $2.7 \mathrm{~cm} \mathrm{~s}^{-1}$ (Fig. 3). Maximum current recorded during the $34 \mathrm{~d}$ sampling

\footnotetext{
1 Reference to trade names does not imply endorsement by the National Marine Fisheries Service
} 
period was $19.4 \mathrm{~cm} \mathrm{~s}^{-1}$. In general, benthic current flowed parallel to shore along the depth contour. The majority of current observations were to the south, with a smaller reciprocal current to the northeast (Fig. 3). Peak southerly currents generally coincided with latter stages of ebbing tides.

Two replicate sediment core samples $(10 \mathrm{~cm}$ height by $5.5 \mathrm{~cm}$ diameter) were collected at the center of the experimental area and examined for grain size characteristics. Surficial sediments (top $3 \mathrm{~cm}$ ) and subsurface sediments ( 3 to $9 \mathrm{~cm}$ depth) of each core were analyzed separately for grain size composition by wet sieving, and graded using the Wentworth classification scale (Wentworth 1922). Sorting was calculated with the inclusive graphic standard deviation (IGSD, Folk \& Ward 1957), with higher values indicating greater grain size variability. The sea whip grove is located on a moderate slope of poorly sorted (IGSD = 1.39) medium and coarse sand (median grain size $=337 \mu \mathrm{m}$ ).

\section{RESULTS}

Simulated trawl damage had significant effects on sea whip physical orientation (i.e. prone versus erect). Dislodged and fractured sea whips were more often prone than the colonies in the abraded and control groups, and the percentage of prone sea whips within the dislodged and fractured treatment groups increased over the duration of the observations (Fig. 4). Fifty percent of dislodged sea whips and $42 \%$ of fractured sea whips were erect $18 \mathrm{~d}$ post-treatment. Only $33 \%$ of dislodged and fractured sea whips were erect $104 \mathrm{~d}$ post-treatment, and at $372 \mathrm{~d}$ post-treatment only one colony $(8.3 \%)$ in each of the dislodged and fractured groups was erect. Contrastingly, all sea whips in

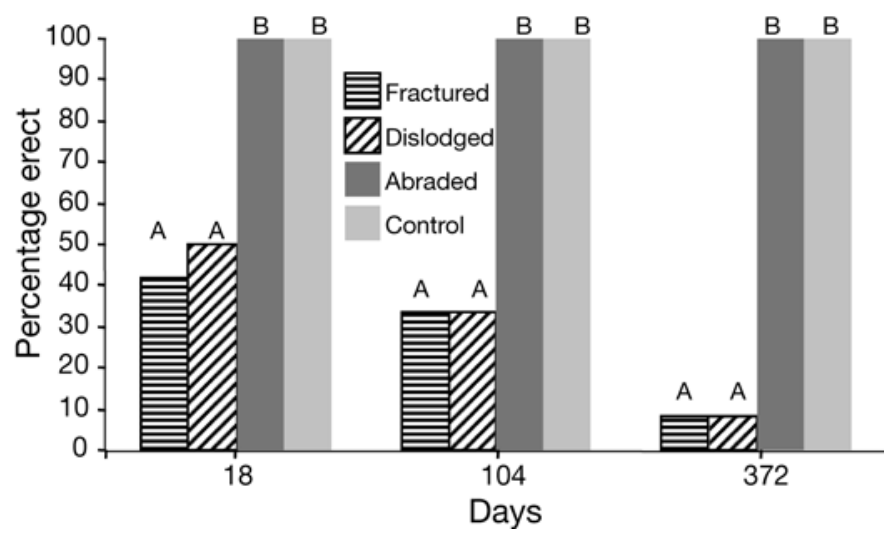

Fig. 4. Halipteris willemoesi. Percentage of erect sea whips 18, 104, and 372 d after trawl damage simulations. Different letters above columns indicate heterogeneity $(\mathrm{p}<0.005)$ among treatments

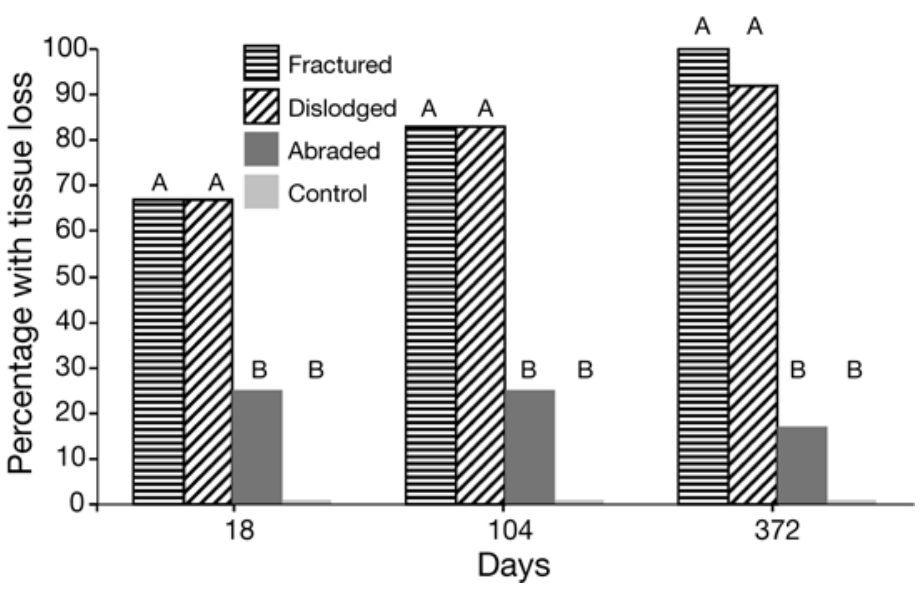

Fig. 5. Halipteris willemoesi. Percentage of sea whips with tissue loss 18, 104, and 372 d after trawl damage simulations. Different letters above columns indicate heterogeneity $(\mathrm{p}<$ 0.005) among treatments

the abraded and control groups remained erect throughout the entire $372 \mathrm{~d}$ observation period. Tests of independence found significant differences $(\mathrm{p}<$ 0.001) in physical orientation between treatment groups at $18(G=23.14), 104(G=30.55)$, and $372 \mathrm{~d}(G=$ 52.44) post-treatment. Heterogeneity tests $(\mathrm{p}<0.005)$ separated the 4 treatments at all 3 sampling dates into 2 distinct groups: one consisting of the dislodged and fractured sea whips and the other consisting of the abraded and control sea whips (Fig. 4).

The percentage of sea whip colonies with tissue loss differed significantly between treatment groups on all 3 sampling dates (Fig. 5). Eighteen days after the simulated trawl damage was performed, $25 \%$ of abraded colonies had minor tissue losses and in some colonies the rachis was twisted. In contrast, $67 \%$ of colonies in both the dislodged and fractured treatment groups exhibited tissue loss $18 \mathrm{~d}$ post-treatment, and for some colonies tissue losses were substantial. After 104 d, little change had occurred among the abraded sea whips and $25 \%$ of the colonies continued to exhibit some loss of tissue. Among the dislodged and fractured groups, the percentage of colonies with tissue loss increased after $104 \mathrm{~d}$. Eighty-three percent of both dislodged and fractured colonies had tissue losses. After $372 \mathrm{~d}$, the abraded sea whips showed fewer signs of trauma, with only $17 \%$ of colonies exhibiting tissue losses. Among the dislodged and fractured sea whips, the percentage of colonies with tissue losses continued to increase. Ninety-two percent of dislodged colonies and $100 \%$ of fractured colonies had substantial tissue losses. In contrast, the control group showed no signs of trauma with $100 \%$ of the tissue intact on all 3 sampling dates. Tests of independence found significant differences $(\mathrm{p}<$ 0.001 ) in the occurrence of tissue loss between treat- 


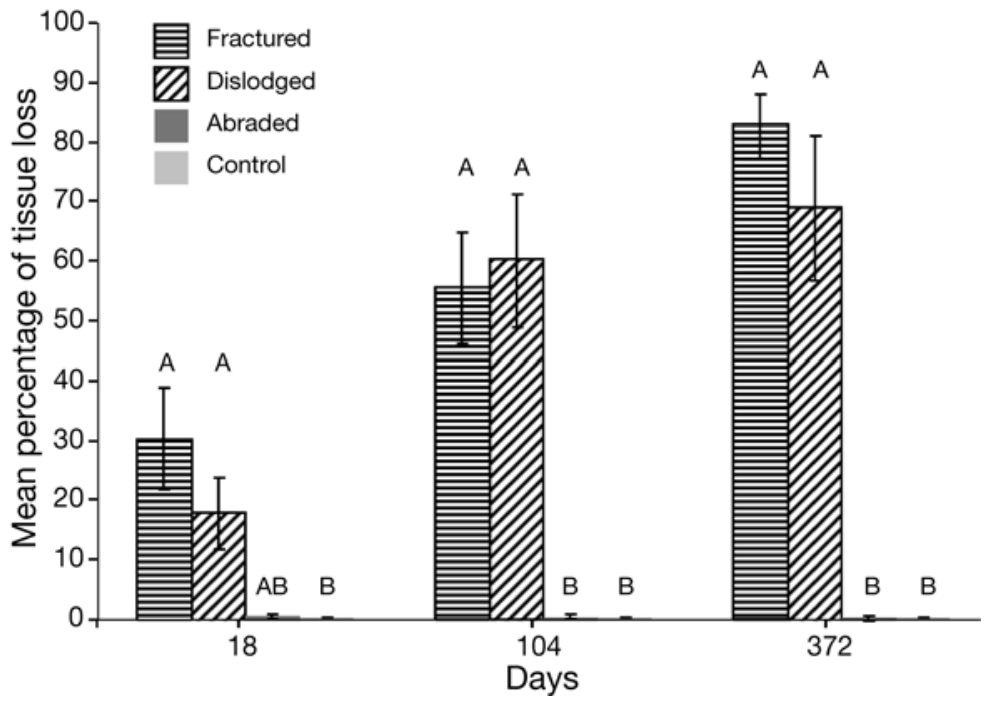

Fig. 6. Halipteris willemoesi. Mean percentage of tissue loss on sea whips at 18, 104, and 372 d after trawl damage simulations. Different letters above bars indicate statistical differences $(p<0.05)$ between treatment groups. Error bars are SE

ment groups at $18(G=20.39), 104(G=31.34)$, and $372 \mathrm{~d}$ $(G=41.93)$ post-treatment. The control and abraded groups were heterogeneous $(p<0.005)$ with the dislodged and fractured groups at all 3 sampling dates (Fig. 5).

The mean percentage of tissue loss per colony differed significantly between treatment groups on all 3 sampling dates (Fig. 6). At 18 d post-treatment, tissue loss among the abraded colonies was very low and the average amount of tissue loss per colony was $0.8 \%$. Average tissue loss among dislodged and fractured colonies was 18.1 and $30.5 \%$, respectively. One fractured colony had lost $81.4 \%$ of its tissue after just $18 \mathrm{~d}$. After $104 \mathrm{~d}$, the average amount of tissue loss in the abraded group decreased to $0.6 \%$, whereas the average amount of tissue loss among dislodged and fractured colonies increased to 60.4 and $55.7 \%$, respectively. After $372 \mathrm{~d}$, the amount of tissue loss among abraded colonies continued to decrease to $0.4 \%$. Among the dislodged colonies, average tissue loss increased to $69.2 \%$. The fractured sea whips fared worse than any other group and average tissue loss among these colonies after 372 d was $82.9 \%$. The least amount of tissue loss within the fractured group after 372 d was $40.7 \%$. Kruskal-Wallis tests were highly significant $(H=18.01$ at $18 \mathrm{~d}, H=27.32$ at $104 \mathrm{~d}$, and $H=38.22$ at $372 \mathrm{~d}, \mathrm{p}<0.005$ ) and nonparametric multiple comparisons separated the 4 treatments into 2 statistically significant groups $(\mathrm{p}<0.05)$ at 104 and $372 \mathrm{~d}$ post-treatment (Fig. 6). The first grouping consisted of control and abraded sea whips, while the second grouping consisted of dislodged and fractured sea whips. The control group, but not the abraded group, differed from the dislodged and fractured groups $18 \mathrm{~d}$ post-treatment (Fig. 6).

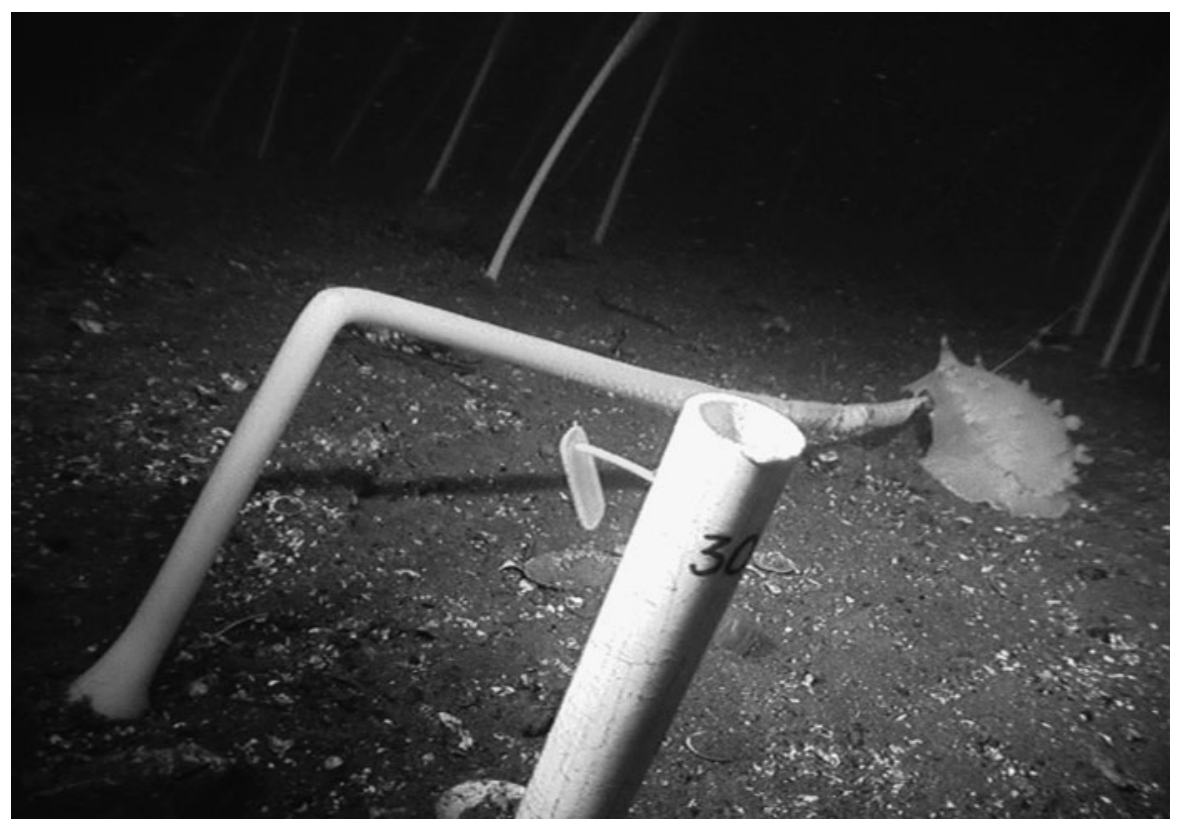

Fig. 7. Halipteris willemoesi and Tritonia diomedea. A prone fractured sea whip $H$. willemoesi being preyed upon by a rosy tritonia nudibranch $T$. diomedea. Note tissue loss and exposed axial rod at distal end of sea whip 
Before the trawl damage simulations were performed, we observed only a few nudibranchs in the study area. However, immediately post-treatment (within $14 \mathrm{~d}$ ) there was an influx of Tritonia diomedea into the study area where they were observed actively feeding on sea whips that were lying on the seafloor. During our censuses, we observed a maximum of 20 individuals within the study area. Predation by $T$. diomedea was a factor influencing sea whip survival. We observed as many as $3 \mathrm{~T}$. diomedea feeding on a single Halipteris willemoesi at one time (Fig. 7). Freshly spawned egg masses of $T$. diomedea were also observed within and near the study area shortly after treatments. The tissues of prone sea whips were not consumed at equal rates. Nudibranchs preferentially consumed the polyp-bearing tissues first and secondarily fed on the peduncles. The area on the rachis between the peduncle and the polyps was not usually consumed and, if so, only small 'bites' were removed.

\section{DISCUSSION}

The opportunity to observe sea whips in situ for $1 \mathrm{yr}$ after subjection to simulated trawl disturbance provided important insights into the recovery potential of these long-lived animals. For example, half of the sea whips we dislodged from the seafloor were able to rebury their peduncles and right themselves, at least initially. We are not aware that this ability has been previously reported for this species, and given their structural simplicity and elongate morphology the feat is quite impressive. Even more impressive is the observation that 2 dislodged sea whips, with considerable tissue damage to the distal portion of their rachises (presumably from predation immediately after dislodgement), were able to rebury their peduncles and right themselves vertically in the water column. These 2 colonies eventually perished on the seafloor and, undoubtedly, the tissue damage they incurred before positioning themselves erect was a considerable stressor that likely contributed to their ultimate demise.

The dislodged sea whips in the present study had the added hindrance of being tethered to their identifying stakes. The tethers may have interfered with the sea whips' ability to bury their peduncles and right themselves. The tethers may also have contributed to the number of sea whips that subsequently fell back to the seafloor after initially standing up. On a few occasions, we observed some tethers fouled with macroalgae; this likely created additional drag that pulled sea whips at the point of attachment when benthic currents were strong. This drag may have been a contributing factor to the mortality of those sea whips that were initially able to right themselves after dislodgement. Additional investigations of dislodged colonies without tethers or comparisons with control colonies equipped with tethers would be useful to further clarify Halipteris willemoesi's ability to survive post-dislodgement.

Halipteris willemoesi in the fractured treatment group also displayed some resilience to simulated trawl damage. Despite broken axial rods, many of these sea whips were able to maintain their rachises off the bottom, often parallel to the seafloor and at right angles to their imbedded peduncles. The polyps on these specimens often appeared healthy and were actively feeding. Although the polyp-bearing tissue on some fractured sea whips was able to survive for a long period of time, we saw no evidence that colonies were capable of repairing their fractured axial rods or aligning and lifting the distal portion of their fractured rachises above their imbedded peduncles. As resilient as the dislodged and fractured $H$. willemoesi were initially, the effects of the simulated trawl damage and subsequent predatory response were eventually devastating. Only one sea whip in each of the dislodged and fractured treatment groups was still erect after $372 \mathrm{~d}$, whereby the single fractured sea whip that was still erect had considerable tissue loss and probably did not survive much past our last observation.

The abraded Halipteris willemoesi in the present study suffered only minor tissue damage when passed through 2 rubber discs to simulate contact with trawl ground gear. The few sea whips that were damaged survived the experimental period and they appeared to repair damaged tissue over time. Optimism in regard to the ability of sea whips to persevere after coming in contact with trawl gear must, however, be tempered by the fact that our method of abrasion was most likely less destructive than an actual trawl since we were not able to duplicate the weight or velocity (i.e. force) of typical commercial gear. Based on submersible observations immediately following experimental trawling in the Gulf of Alaska, trawl-induced tissue damage to sea whips is often more severe than that inflicted in the present study (P. Malecha pers. obs.). Therefore, the actual long-term effects of tissue damage from trawls may be greater than what we observed among sea whips in the abraded treatment group. Regardless of whether or not trawling activities are more destructive than our treatments, even the smallest tissue injuries may decrease the ability of sea whips to reproduce. In warm-water corals, stress can reduce reproductive output, because energy is allocated to wound repair rather than to gamete or larvae production (Wahle 1983, Van Veghel \& Bak 1994), and induce premature release of gametes and abortion of planulae (Loya \& Rinkevich 1979, 1980, Szmant-Froelich et al. 1980, Fadlallah 1983), resulting in unsuccessful recruitment (Loya \& Rinkevich 1979). Similarly, mechanical distur- 
bance of the cold-water coral Gersemia spp. can induce premature release of highly unviable planulae (Henry et al. 2003). Aside from diminished reproductive fitness, injured corals also have lower growth rates (Yoshioka \& Yoshioka 1991, Meesters et al. 1994), and reduced competitive abilities against encroachment from neighboring organisms (Aerts 2000).

The fate of the dislodged and fractured sea whips in the present study illustrates the direct negative effect of trawl disturbance on sea whips. Furthermore, trawl disturbance to sea whips often results in a combination of injuries, including abrasion, fracture, and dislodgement (P. Malecha pers. obs.), that likely has compounding negative effects on their survival. Because they grow slowly and are long-lived (Wilson et al. 2002), trawl impacts on Alaskan sea whip populations may have lasting effects, especially considering that reproduction may be sporadic. Bottom trawling may have caused long-term effects on sea whip groves in the Gulf of Alaska where large sea whips $(>80 \mathrm{~cm}$ ) were less than half as abundant in areas open to trawling than in areas immediately adjacent but closed to trawling - perhaps suggesting a shift in size frequency as a result of an 11 to 12 yr trawl closure (Stone et al. 2005).

Trawl damage to sea whips may indirectly have negative consequences on the benthic communities they support. For example, the density of prey species commonly utilized by commercially important groundfish is greater in areas with high sea whip abundance compared to areas immediately adjacent but with low abundance of sea whips (Stone et al. 2005). Therefore, loss of sea whip habitat due to mortalities from bottom trawling could reduce prey fields and subsequently inhibit the ability of the habitat to support large numbers of commercially important species, including Pacific ocean perch which utilize sea whip habitat in the Bering Sea (Brodeur 2001).

Opportunistic predation by the nudibranch Tritonia diomedea likely reduced the ability of the sea whips to recover from dislodgement and fracture; therefore, the present study may underestimate the ability of Halipteris willemoesi to recover from trawl disturbances when predators are absent. However, in areas where predators are present, trawling disturbances to sea whips may stimulate a predation response that exacerbates trawling effects. Dislodged and fractured $H$. willemoesi lying on the seafloor were vulnerable to predation by $T$. diomedea. The nudibranchs appeared to react with a strong scavenging/predatory response to prone sea whips. T. diomedea are known to be attracted to food stimuli (Willows 1978) and before the simulated trawl treatments were performed, we observed only $3 T$. diomedea in the experimental area. After the treatments were performed, we consistently observed 18 individuals and at times even as many as 20. The presence of $T$. diomedea complicates the results of the present study by blending the effects due specifically to trawling with those due to predation. The combined effects most likely exceed the immediate effects due to trawl disturbances alone. However, in the natural environment, trawl damage to sea whips does not occur in a vacuum but likely amongst predators. Therefore, the results presented here may accurately depict real processes that occur when trawls disturb sea whips.

Natural predators of pennatulaceans in Alaska have not been well inventoried. However, Tritonia diomedea is known to feed on several pennatulacean species and prefers sea whips of the genus Virgularia to the sea pen Ptilosarcus gurneyi (Willows 1978, Audesirk \& Audesirk 1979). Other predators of sea whips likely exist, given the fact that several predators of $P$. gurneyi have been documented in Puget Sound, Washington, including several sea stars (Hippasteria spinosa, Dermasterias imbricata, Crossaster papposus, and Mediaster aequalis) and nudibranchs (Armina californica, T. festiva, and Hermissenda crassicornis) (Birkeland 1974). In addition to $T$. diomedea, we also occasionally observed predatory snails, crabs, and other nudibranch species apparently scavenging on prone sea whips.

Because pennatulaceans have a limited ability to flee, it would appear that they are extremely vulnerable to predation. However, aside from flight, sea whips may have other types of defenses. Several studies have examined the defense capabilities of octocorals, especially gorgonians (Pawlik et al. 1987, Harvell \& Fenical 1989, Lapid \& Chadwick 2006). Both structural (Gerhart et al. 1988, Harvell et al. 1988, Van Alstyne \& Paul 1992, Van Alstyne et al. 1992) and chemical (Pawlik et al. 1987, Harvell et al. 1988, Van Alstyne \& Paul 1992, Van Alstyne et al. 1992) attributes of octocorals have demonstrated significant anti-predator defenses against fish and invertebrate predators. For those colonies lying on the seafloor, most of the peduncles and the tissues of the rachis below the polyps (approximately $15 \mathrm{~cm})$ were generally not consumed by Tritonia diomedea. Additionally, predation by nudibranchs on erect Halipteris willemoesi in the abraded and control groups did not occur. The disinclination of $T$. diomedea to prey on the lower portion of sea whips lying on the seafloor and their inability to prey on erect colonies perhaps suggests that $H$. willemoesi may have structural and/or chemical defenses on the tissue above their peduncles that deter epibenthic predators. Typically, chemical defenses are concentrated at the distal portions of colonies where polyp density is greatest, whereas structural defenses are often concentrated near the base of colonies (Harvell \& Fenical 1989, 
Wylie \& Paul 1989). The distribution of defenses is perhaps an adaptation to various types of predators and their mode of attack. Therefore, if sea whips have evolved defensive structures located at the base of the colony that are specific to epibenthic, non-swimming predators such as nudibranchs and sea stars, the defenses certainly do not provide protection when sea whips are not erect. Disturbed animals, especially those lying on the seafloor, may be more vulnerable to predation from a wider array of predators since the defenses at their polyps may not be adaptively effective against non-swimming predators. Further study could examine the possible chemical and/or structural defenses of sea whips that are common among octocorals.

Trawl disturbances have both immediate and longterm consequences that affect sea whip survival. The results of the present study provide valuable information regarding delayed mortality and sublethal injuries suffered by sea whips as a result of trawling. Our findings indicate that the outlook for dislodged and fractured sea whips is very poor. Therefore, the benthic communities that sea whips support are at risk if trawling disturbances are widespread and persistent. Although the present study focuses on damage due specifically to trawling, other fishing gears that come in contact with the seafloor may also disturb sea whips. Presumably, scallop dredges and trawls have similar interactions with sea whips, since both gears are mobile and fished in a similar manner. Entanglement and abrasion are possible when longlines come in contact with sea whips, and crab and fish traps may crush sea whips when deployed to the seafloor. As ecosystem management and habitat conservation become more prevalent, fishers and fisheries managers must understand fishery consequences and should use prudence when prosecuting fisheries that have the potential to adversely affect sea whips and seafloor ecosystems.

Acknowledgements. The authors thank Capt. C. Lunsford, dive tender and pilot of the RV 'Quest', and D. Courtney and A. Wertheimer who assisted with scuba operations. This manuscript also benefited from insightful comments by several anonymous reviewers.

\section{LITERATURE CITED}

Aerts LAM (2000) Dynamics behind standoff interactions in three reef sponge species and the coral Montastraea cavernosa. PSZN I Mar Ecol 21:191-204

Audesirk TE, Audesirk GJ (1979) Oral mechanoreceptors in Tritonia diomedea. II. Role in feeding. J Comp Physiol A 130:79-86

Auster PJ, Langton RW (1999) The effects of fishing on fish habitat. In: Benaka L (ed) Fish habitat: essential fish habitat and rehabilitation. Am Fish Soc Symp 22. Bethesda, MD, p 150-187
Auster PJ, Malatesta RJ, Langton RW, Watling L and others (1996) The impacts of mobile fishing gear on seafloor habitats in the gulf of Maine (Northwest Atlantic): implications for conservation of fish populations. Rev Fish Sci 4: 185-202

Birkeland C (1974) Interactions between a sea pen and seven of its predators. Ecol Monogr 44:211-232

Brodeur RD (2001) Habitat-specific distribution of Pacific ocean perch (Sebastes alutus) in Pribilof Canyon, Bering Sea. Cont Shelf Res 21:207-224

> Collie JS, Hall SJ, Kaiser MJ, Poiner IR (2000) A quantitative analysis of fishing impacts on shelf-sea benthos. J Anim Ecol 69:785-798

> Fadlallah YH (1983) Sexual reproduction, development and larval biology in scleractinian corals. Coral Reefs 2:129-150

> Floderus S, Pihl L (1990) Resuspension in the Kattegat: impact of variation in wind climate and fishery. Estuar Coast Shelf Sci 31:487-498

Folk RL, Ward WD (1957) Brazos River bar (Texas); a study in the significance of grain size parameters. J Sediment Res $27: 3-36$

> Freese L, Auster PJ, Heifetz J, Wing BL (1999) Effects of trawling on seafloor habitat and associated invertebrate taxa in the Gulf of Alaska. Mar Ecol Prog Ser 182:119-126

Gerhart DJ, Rittschof D, Mayo SW (1988) Chemical ecology and the search for marine antifoulants: studies of a predator-prey symbiosis. J Chem Ecol 14:1905-1917

Harvell CD, Fenical W (1989) Chemical and structural defenses of Caribbean gorgonians (Pseudopterogorgia spp.): intracolony localization of defense. Limnol Oceanogr 34: 382-389

> Harvell CD, Fenical W, Greene CH (1988) Chemical and structural defenses of Caribbean gorgonians (Pseudopterogorgia spp.). I. Development of an in situ feeding assay. Mar Ecol Prog Ser 49:287-294

> Henry LA, Hart M (2005) Regeneration from injury and resource allocation in sponges and corals: a review. Int Rev Hydrobiol 90:125-158

> Henry LA, Kenchington ELR, Silvaggio A (2003) Effects of mechanical experimental disturbance on aspects of colony responses, reproduction, and regeneration in the coldwater octocoral Gersemia rubiformis. Can J Zool 81: 1691-1701

Kaiser MJ, Collie JS, Hall SJ, Jennings S, Poiner IR (2002) Modification of marine habitats by trawling activities: prognosis and solutions. Fish Fish 3:114-136

> Lapid ED, Chadwick NE (2006) Long-term effects of competition on coral growth and sweeper tentacle development. Mar Ecol Prog Ser 313:115-123

> Loya Y, Rinkevich B (1979) Abortion effect in corals induced by oil pollution. Mar Ecol Prog Ser 1:77-80

> Loya Y, Rinkevich B (1980) Effects of oil pollution on coral reef communities. Mar Ecol Prog Ser 3:167-180

Malecha PW, Stone RP, Heifetz J (2005) Living substrate in Alaska: distribution, abundance and species associations. In: Barnes PW, Thomas JP (eds) Benthic habitats and the effects of fishing. Am Fish Soc Symp 41, Bethesda, MD, p 289-299

> Meesters EH, Noordeloos M, Bak RPM (1994) Damage and regeneration: links to growth in the reef-building coral Montastrea annularis. Mar Ecol Prog Ser 112:119-128

National Research Council (2002) Effects of trawling and dredging on seafloor habitat. National Academy Press, Washington, DC

Pawlik JR, Burch MT, Fenical W (1987) Patterns of chemical defense among Caribbean gorgonian corals: a preliminary survey. J Exp Mar Biol Ecol 108:55-66 
Rose CS, Jorgensen EM (2005) Spatial and temporal distributions of bottom trawling off Alaska: consideration of overlapping effort when evaluating the effects of fishing on habitat. In: Barnes PW, Thomas JP (eds) Benthic habitats and the effects of fishing. Am Fish Soc Symp 41, Bethesda, MD, p 679-690

Sokal RR, Rohlf FJ (1995) Biometry: the principles and practice of statistics in biological research, 3rd edn. WH Freeman, New York

Stone RP, Shotwell SK (2007) State of deep coral ecosystems in the Alaska Region: Gulf of Alaska, Bering Sea and the Aleutian Islands. In: Lumsden SE, Hourigan TF, Bruckner AW, Dorr G (eds) The state of deep coral ecosystems of the United States. NOAA Tech Memo CRCP-3, Silver Spring, MD, p 65-108

Stone RP, Masuda MM, Malecha PW (2005) Effects of bottom trawling on soft-sediment epibenthic communities in the Gulf of Alaska. In: Barnes PW, Thomas JP (eds) Benthic habitats and the effects of fishing. Am Fish Soc Symp 41, Bethesda, MD, p 461-475

Szmant-Froelich AM, Yevich P, Pilson MEQ (1980) Gametogenesis and early development of the temperate coral Astrangia danae (Anthozoa: Scleractinia). Biol Bull 158: 257-269

Troffe PM, Levings CD, Piercey GE, Keong V (2005) Fishing gear effects and ecology of the sea whip (Halipteris willemoesi (Cnidaria: Octocorallia: Pennatulacea)) in British Columbia, Canada: preliminary observations. Aquat Conserv 15:523-533

Van Alstyne KL, Paul VJ (1992) Chemical and structural defenses in the sea fan Gorgina ventalina: effects against generalist and specialist predators. Coral Reefs 11:155-159

Editorial responsibility: Charles Birkeland, Honolulu, Hawaii, USA
Van Alstyne KL, Wylie CR, Paul VJ, Meyer K (1992) Antipredator defenses in tropical Pacific soft corals (Coelenterata: Alcyonacea). I. Sclerites as defenses against generalist carnivorous fishes. Biol Bull 182:231-240

- Van Veghel MLJ, Bak RPM (1994) Reproductive characteristics of the polymorphic Caribbean reef building coral Montastrea annularis. III. Reproduction in damaged and regenerating colonies. Mar Ecol Prog Ser 109:229-233

von Kölliker RA (1870) Anatomisch-systematische Beschreibung der Alcyonarien. I. Die Pennatuliden. Abh Senckenb Natforsch Ges 7:487-602

Wahle CM (1983) The roles of age, size, and injury in sexual reproduction among Jamaican gorgonians. Am Zool 23: 961

Watling L, Norse EA (1998) Disturbance of the seabed by mobile fishing gear: a comparison to forest clearcutting. Conserv Biol 12:1180-1197

Wentworth CK (1922) A scale of grade and class terms for clastic sediments. J Geol 30:377-392

> Willows AOD (1978) Physiology of feeding in Tritonia. I. Behavior and mechanics. Mar Behav Physiol 5:115-135

Wilson MT, Andrews AH, Brown AL, Cordes EE (2002) Axial rod growth and age estimation of the sea pen, Halipteris willemoesi Kölliker. In: Watling L, Risk M (eds) Biology of cold water corals. Hydrobiologia 471:133-142

Wylie CR, Paul VJ (1989) Chemical defenses in three species of Sinularia (Coelenterata, Alcyonacea): effects against generalist predators and the butterflyfish Chaetodon unimaculatus Bloch. J Exp Mar Biol Ecol 129:141-160

Yoshioka PM, Yoshioka BB (1991) A comparison of the survivorship and growth of shallow-water gorgonian species of Puerto Rico. Mar Ecol Prog Ser 69:253-260

Submitted: February 27, 2009; Accepted: June 7, 2009 Proofs received from author(s): August 6, 2009 